\title{
A new species of critically endangered edible yam endemic to northern Madagascar, Dioscorea irodensis (Dioscoreaceae) and its conservation
}

\author{
Paul Wilkin $^{1}$ (D) James A. Kennerley ${ }^{2}$, Mamy Tiana Rajaonah ${ }^{3}$, Geodain Meva Huckël ${ }^{4}$, \\ Feno Rakotoarison ${ }^{4}$, Tianjanahary Randriamboavonjy ${ }^{3}$ \& Stuart Cable ${ }^{1}$
}

Summary. Morphological character data are used to show that a distinct morphotype of Dioscorea L. from the Irodo valley (East of Sadjoavato) in Antsiranana Province of Madagascar is an undescribed species, differing in its leaf arrangement, pubescence form and male inflorescence structure from all other taxa. It is described as Dioscorea irodensis Wilkin, Rajaonah \& Randriamb., illustrated and a distribution map and ecological information provided. It is known from three sites, but is likely to have been eradicated from one of them. The population that has been studied in the field contains a very low number of adult plants. Tubers have been extracted for use as food at a level that appears to be unsustainable. Thus its provisional IUCN conservation status assessment is that it is critically endangered (CR). Its vernacular name in Irodo is Bemandry.

Famintinana. Ny toetra sy ny bikan'ny oviala dia azo ampiasaina hanehoana fa miavaka ny oviala iray, izay hita tao anatin'ny lohasahan'Irodo (Atsinanan'i Sadjoavato, faritanin'Antsiranana) ao Avaratr'i Madagasikara, ary tsy mbola voasoritra ny mombamomba azy. Mampihavaka azy amin'ny hafa ireto toetra manaraka ireto: ny fipetraky ny ravina, ny fisian'ny volo, sy ny firafitry ny tahom-bony lahy eo aminy. Nosoritana ho Dioscorea irodensis Wilkin, Rajaonah \& Randriamb. izy ity, nampiratiana an-tsary ny momba azy, namoahana saritany ny toerana misy azy, ary nomena ireo vaovao ara-ekolojika mikasika azy. Vondrona oviala miisa telo fara-faha-betsany no fantatra fa misy azy, ary efa ho fongana ny iray amin'ireo. Ny vokatry ny fanadihadiana izay natao tamin'ny vondrona oviala misy no nahitana fa vitsy ny fototra oviala lehibe afaka mamoa, ary maro ireo nohadiana ho sakafo, izay mamaritra sahady fa tsy hateza io karazana io. Noho izany, ny sata fiarovana vonjimaika IUCN dia manombana fa zavamaniry tena tandindomin-doza (CR) io karazana oviala io. Bemandry no fiantso io karazana oviala io any Irodo.

Key Words. conservation, critically endangered, distribution, edible, ex situ, in situ, Madagascar, morphology, new species, yam.

\section{Introduction}

The taxonomic and nomenclatural history of Dioscorea in Madagascar was summarised in Wilkin \& Randriamboavonjy (2012). Since the publication of that paper, field research in the North of the country has been undertaken by the authors of this paper under the project "Conserving Madagascar's yams through cultivation for livelihoods and food security", funded by the UK Darwin Initiative. This led to the discovery of a morphotype collected from three sites east of the RN6 near Sadjoavato in Antsiranana Province that potentially represented a new taxon. The morphotype has extensive and sometimes dense pubescence and vegetative stem leaves in clusters on short shoots, traits it shares with $D$. ovinala Baker. Two taxa of the D. sambiranensis R. Knuth complex (Wilkin et al. 2009) are also pubescent (D. sambiranensis and D. namorokensis Wilkin) but their leaves are always borne singly in an alternate arrangement. The first specimen collected of the morphotype was misidentified as D. sambiranensis, which has similar indumentum but in addition to the leaf arrangement, differs in having a longpedicellate male flower (Wilkin et al. 2009), flat discoid floral torus and thicker leaf blades. Elements of the D. soso Jum. \& H. Perrier complex, found further south, also have

\footnotetext{
Accepted for publication 26 January 2017. Published online 4 April 2017

1 Royal Botanic Gardens, Kew, Richmond, Surrey, TW9 3AE, UK. e-mail: p.wilkin@kew.org

216 Coppice Close, Woodbridge, Suffolk, IP12 1RX, UK.

3 Kew Madagascar Conservation Centre (KMCC), II JJ 131 B, Ambodivoanjo Ivandry - 101, Antananarivo, Madagascar

4 Kew Madagascar Conservation Centre (KMCC), Tanambao Mission - 203 Ambanja, Antsiranana, Madagascar.
} 
similar indumentum, however these taxa also have solitary, alternate leaves and short petioles in relation to blade length, by which they differ from $D$. ovinala and the plants from East of Sadjoavato. Thus this entity was compared with $D$. ovinala to assess its taxonomic status.

\section{Materials \& Methods}

The hypothesis that the morphotype from East of Sadjoavato represents a distinct taxon was tested by morphological comparison with existing species of Dioscorea from Madagascar as defined in the introduction. The most detailed comparison was made with $D$. ovinala. Knowledge of the systematics of the yams of Madagascar is based on comparative morphological study and a database of 1346 specimens from the following herbaria: B, BM, G, K, MO, P, TAN, TCD, TEF, UPS and WAG (herbarium acronyms follow Thiers (2012)) and in the field. The specimens examined in the study of the new species are cited below. Floral dissections were carried out and measurements made using a Leica MZ95 with a measuring eyepiece. Vegetative and inflorescence characters were measured with a dial caliper.

Digital latitude and longitude of the four specimens of the morphotype were used to generate Map 1, which was created with SimpleMappr (Shorthouse 2010; http:// www.simplemappr.net). These data were also imported into GeoCAT (Bachman et al. 2011; http://geocat.kew.org/) in order to calculate extent of occurrence (EOO) and area of occupancy (AOO).

\section{Results and Discussion}

The fruit, seed and tuber morphology of the specimens examined unequivocally place the morphotype from East of Sadjoavato within the Malagasy clade of Dioscorea (Wilkin et al. 2005; Viruel et al. 2016). This result is further corroborated by unpublished phylogenetic analyses of multiple plastid markers. There are clear vegetative and reproductive morphological differences between the new entity and all other known species (see Introduction and Table 1). Thus it is described as a new species, $D$. irodensis Wilkin, Rajaonah \& Randriamb. below.

GeoCAT yielded figures of $7.3 \mathrm{~km}^{2}$ for EOO CR and 12 $\mathrm{km}^{2}$ for AOO based on a user defined cell width of $2 \mathrm{~km}$, as recommended by IUCN Standard and Petitions Subcommittee (2014). Both the EOO and AOO are below the thresholds for categorisation as EN; the EOO is also below the threshold for categorisation as CR (IUCN 2001).

\section{Taxonomic Description}

Dioscorea irodensis Wilkin, Rajaonah $\mathcal{E}$ Randriamb., sp. nov. Type: Madagascar, Antsiranana: Diana, Antsiranana II, Anivorano, Irodo, ala fady $\mathrm{S}$ of village towards Irodo river estuary, $12^{\circ} 39^{\prime} 6.3^{\prime \prime} \mathrm{S} 4^{\circ} 31^{\prime} 38.2^{\prime \prime} \mathrm{E}$, + fr. 8 Feb. 2015, P. Wilkin, J. A. Kennerley, F. Rakotonasolo, M. Hamido $\mathcal{E}^{2}$ M. Tsaratiana 1675 (holotype TAN!; isotype K!).

http:/ /www.ipni.org/urn:lsid:ipni.org:names:77159808-1

A twining vine to c. $6 \mathrm{~m}$ in height. Current season's tuber (Fig. 2C) (previous seasons' also present) to c. 80

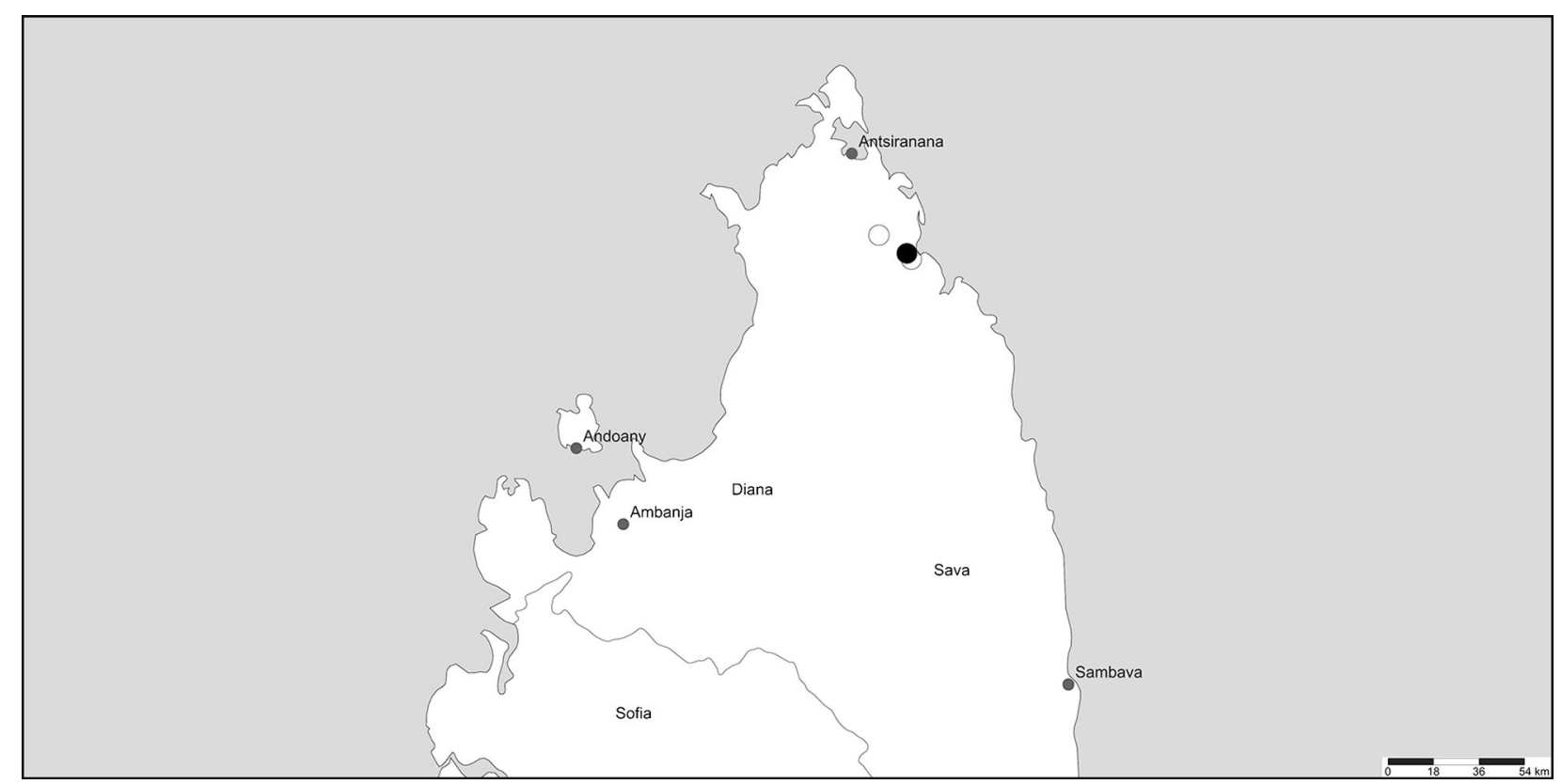

Map 1. Map showing the distribution of Dioscorea irodensis specimens in northern Madagascar. The known population is indicated by solid black circles (two overlapping points). Populations of unknown status or potentially eradicated are indicated by open circles (one point partially overlapping solid black points; see also Conservation Status section). Major population centres (grey circles) and subprovinces are indicated. 
Table 1. A comparison of the principal characters differentiating Dioscorea irodensis from D. ovinala.

\begin{tabular}{|c|c|c|}
\hline Character & D. ovinala & D. irodensis \\
\hline Tuber habit and size & $\begin{array}{l}\text { Vertical in substrate, } 50-100 \times 10-15 \mathrm{~cm} \text {, } \\
\text { fusiform }\end{array}$ & $\begin{array}{l}\text { Horizontal in substrate, to c. } 80 \times 15 \mathrm{~cm} \text {, } \\
\text { cylindric }\end{array}$ \\
\hline Indumentum & $\begin{array}{l}\text { Often dense, velutinous and soft to touch, } \\
\text { especially on leaf lower surface and } \\
\text { inflorescences }\end{array}$ & $\begin{array}{l}\text { Sometimes dense but coarse rather than soft } \\
\text { and velutinous }\end{array}$ \\
\hline Leaf arrangement & $\begin{array}{l}\text { Solitary to in clusters of up to } 4 \text { on short } \\
\text { herbaceous branches }\end{array}$ & $\begin{array}{l}\text { Usually in clusters of up to } 7 \text { on short } \\
\text { herbaceous branches, especially on primary } \\
\text { vegetative shoots, sometimes solitary towards } \\
\text { shoot apices }\end{array}$ \\
\hline Leaf texture & $\begin{array}{l}\text { Chartaceous to thickly so, not translucent even } \\
\text { when dry }\end{array}$ & $\begin{array}{l}\text { Thinly chartaceous to membranous, sometimes } \\
\text { translucent when dry }\end{array}$ \\
\hline Male inflorescence & $\begin{array}{l}1 \text { - } 4 \text { flowers per node, dense, sessile or rarely } \\
\text { with a pedicel to } 0.5 \mathrm{~mm} \text { long }\end{array}$ & $\begin{array}{l}\text { Dense cymular clusters of }(1-) 2-8 \text { flowers on } \\
0.2-1.1 \mathrm{~mm} \text { long pedicels }\end{array}$ \\
\hline $\begin{array}{l}\text { Male flower habit and tepal } \\
\text { shape }\end{array}$ & $\begin{array}{l}\text { Tepals spreading, making flower rotate, tepals } \\
\text { ovate with obtuse apices }\end{array}$ & $\begin{array}{l}\text { Tepals ascending with recurving apices, making } \\
\text { flower shallowly bowl-shaped, ovate to elliptic } \\
\text { or broadly so with rounded to acute apices }\end{array}$ \\
\hline $\begin{array}{l}\text { Fruit dimensions and outline } \\
\text { shape }\end{array}$ & $26-40 \times 17-30 \mathrm{~mm}$, obovate to suborbicular & $23-28 \times 15-19 \mathrm{~mm}$, obovate to oblong-obovate \\
\hline $\begin{array}{l}\text { Fruit wing form during } \\
\text { development }\end{array}$ & $\begin{array}{l}\text { Each wing c. } 4-5 \mathrm{~mm} \text { thick and fleshy when } \\
\text { immature, when dry with clearly } \\
\text { differentiated exocarp }\end{array}$ & $\begin{array}{l}\text { Immature wing thickness not exceeding } 1 \mathrm{~mm} \text {, } \\
\text { not fleshy, when dry wing single-layered. }\end{array}$ \\
\hline
\end{tabular}

$\times 15 \mathrm{~cm}$, cylindric, tapering towards base and apex, horizontal in substrate, c. $20-50 \mathrm{~cm}$ deep, epidermis pale cream, parenchyma pure white, watery, not mucilaginous, apex curved $90^{\circ}$ and narrowing to c. 3 $\mathrm{mm}$, subtended by a c. $8 \mathrm{~mm}$ diam., thickened crown; stem above crown erect, annual, below ground white, above ground to $3 \mathrm{~mm}$ in diam., terete, unarmed, tough and wiry, dark purple with green flecks to brown and mottled paler, drying dark brown on principal stems, paler on branches, possessing cataphylls towards stem base to c. $4 \times 3 \mathrm{~mm}$, very broadly ovate, apex acute to short-acuminate, amplexicaul, thick and leathery; axillary bulbils not present; nodes on main stems and towards base especially swollen to c. $6 \mathrm{~mm}$, often with a pair of rigid, aculeate lateral projections, occasionally more projections present. Indumentum coarse, of colourless multicellular hairs with small inflated bases, to $1.5 \mathrm{~mm}$ long, erect to spreading and straight to curved, basal stems subglabrous, pubescence more extensive at nodes and on younger (narrower and angled) stems, dense on petioles and leaf blade, (lower surface less so with age), densest on buds and leaves in early stages of expansion (during male anthesis), inflorescences pubescent, most densely so on cymule bracts and tepal dorsal surfaces, especially outer whorl, capsules glabrescent but less so along axis and around style base. Leaves borne in clusters of up to 7 on short herbaceous branches, especially on principal stems, sometimes solitary, especially on narrower stem branches and towards apices, alternate, blade (20 -) $29-71 \times(14-) 22-75 \mathrm{~mm}$, ovate to very broadly so or ovate-orbicular, entire, thinly herbaceous when fresh, thin and sometimes papery when dry, some- times translucent, drying grey to pale olive-green, paler below, paler narrowly oblong micro-organs visible at high magnification, definition and density variable, when fresh blade dark green above, paler below, veins $5-7,3$ reaching apex, base cordate to subtruncate, sinus depth to $8 \mathrm{~mm}$, apex rounded or obtuse to acute or short-acuminate, with a forerunner tip to c. $2.5 \times 1.2 \mathrm{~mm}$, deltoid, green to weakly brownpigmented when fresh, drying dark brown to concolorous with blade; petiole 10 - $54 \mathrm{~mm}$ long, slender, not exceeding $0.5 \mathrm{~mm}$ in diam. in dried material, terete but longitudinally ridged, lacking a differentiated upper channel, concolorous with leaf upper surface to paler and browner, pulvinii when fresh pale green, indistinguishable when dry, central part concolorous with stem or paler. Inflorescences 1 per axil, spiciform, pendent; male inflorescences borne in axils of leaves that do not exceed c. $1 \mathrm{~cm}$ long (in early development) and appear grey-brown due to pubescence, axis to $155 \mathrm{~mm}$ long (including 3-11 $\mathrm{mm}$ long peduncle), slender like petiole, angled, bearing spirally arranged, irregularly spaced dense cymules of $2-8$ flowers, rarely a solitary flower, subtended by a $1.4-$ $2.1 \times 0.4-0.6 \mathrm{~mm}$, elliptic-acuminate cymule bract, each node of cymule with a $0.9-1.3 \times 0.2-0.4 \mathrm{~mm}$ floral bract, similar to cymule bract but narrowly elliptic-acuminate to linear. Male flowers purple, shallowly bowl-shaped, on $0.2-1.1 \mathrm{~mm}$ long pedicels that are swollen immediately below torus, the latter 0.6 $0.8 \mathrm{~mm}$ in diam., shallowly concave, opaque when dry; tepals 6, outer whorl weakly differentiated (slightly narrower), ovate to elliptic or broadly so, free, inserted on torus margin, ascending, upper half recurved at anthesis, translucent except midrib, apex rounded to 
acute, sometimes cucullate, outer tepals $1.1-1.3 \times 0.5-$ $0.8 \mathrm{~mm}$, inner tepals $1.0-1.3 \times 0.6-0.9 \mathrm{~mm}$; stamens inserted on torus margin, erect, filaments 0.05 $0.1 \mathrm{~mm}$ long, stout, anthers $0.25-0.35 \times 0.25-0.35$ $\mathrm{mm}$, broadly oblong-orbicular, basifixed; pistillode 3 ridges at torus centre at $120^{\circ}$ to each other, c. $0.2 \mathrm{~mm}$ in diam. $\times 0.05 \mathrm{~mm}$ high. Female inflorescences unknown. Infructescences $38-135 \mathrm{~mm}$ long, peduncle $8-30 \mathrm{~mm}$ long, axis colour as stems. Capsule 23-28×15-19 mm, ascending at c. $75^{\circ}$ to axis at dehiscence on recurved pedicels, obovate to oblong-obovate in outline, base rounded to truncate, apex obtuse to weakly retuse, styles persistent as a lobed apiculus, dehiscing from apex, immature capsule not seen, (sub)mature with wing thickness not exceeding $1 \mathrm{~mm}$, not fleshy, pale straw-brown with red-brown markings, when mature each wing single-layered, uniformly pale to mid brown or specked with darker brown or grey-brown when dry. Seed winged at base only, $5.6-8.0 \times 3.4-5.1 \mathrm{~mm}$ (excluding wing), obovate in outline, dark brown, base rounded to acute, apex obtuse to rounded, wing $5.7-$ $11.2 \times 5.2-6.7 \mathrm{~mm}$, papery and translucent chestnut brown. Figs 1, 2.

RECOGNITION. Tuber horizontal in soil with a curved apex (derived from digging up two plants and inferring a similar position in others from the shape of extraction holes and the Malagasy vernacular name). Leaves in clusters of up to 7 on short herbaceous branches, clustered particularly towards bases of main vegetative stems (Fig. 1A, 2B), blades thin in texture, densely pubescent below and when immature but coarse and never forming a tomentum as in Dioscorea ovinala. Plants at the locality near Irodo represented by Wilkin et al. 1674 and 1675 often have white spotting on their leaf blades which has the appearance of pathogenic infection (see Fig. 2A). Male inflorescences (Fig. $1 \mathrm{E}, \mathrm{F}$ ) with irregularly spaced, spirally arranged dense cymules of $2-8$ pedicellate flowers or rarely solitary, vs flowers (sub)sessile, or rarely with a pedicel to $0.5 \mathrm{~mm}$ long and solitary or in groups of $2-4(D$. ovinala). Fruit not inflated and fleshy during development but thin-lobed and capsular throughout, single layered at dehiscence. Restricted to a small area East of Sadjoavato in Antsiranana Province.

DISTRIBUTION AND HABITAT. Endemic to the Irodo river Valley and Sahafary forest in Antsiranana Province (Map 1) at altitudes from $30-230 \mathrm{~m}$. It is possible that the three collections from South of the village of Irodo represent two subpopulations on either side of the river as opposed to two distinct populations (the term population is used here in an ecological sense, except in the Conservation Status section), but the specimen from Sahafary forest is spatially isolated. At Irodo, it is found in semi-deciduous forest with a canopy to $10 \mathrm{~m}$ and a clear shrub layer, the principal canopy trees being Colvillea and Tamarindus, with Pachypodium in the shrub layer. Soil a brown sandy loam, possibly alluvial, or red sand over limestone bedrock. The Sahafary Forest specimen states that it was from scrub forest on red sand. SPECIMENS EXAMINED. MADAGASCAR. Antsiranana Province: Sahafary Forest, Analakay Forest, E of National Route \#6, 12³5'03"S 49²5'08"E, ô fl. \& + immat. fr., 8 Nov. 2006, Z. S Rogers, R. Ranaivojaona, C. Davidson, S. R. Christoph E $\mathcal{F}$ F. Ratov 1149 (K!, MO); Analamera, bank of Irodo R., near Irodo camp, $12^{\circ} 40^{\prime} 25^{\prime \prime S} 49^{\circ} 32^{\prime} 40^{\prime \prime} \mathrm{E}$, 우 immat. fr 6 Jan. 2002, P. De Block, F. Rakotonasolo $\mathcal{E} T$ T. Randriamboavonjy 1079 (BR, K!, K000523804); Diana, Antsiranana II, Anivorano, Irodo, ala fady $\mathrm{S}$ of village towards Irodo river estuary, $12^{\circ} 39^{\prime} 6.2^{\prime \prime} \mathrm{S} 49^{\circ} 31^{\prime} 37.9^{\prime \prime} \mathrm{E}$, old ô fl. 8 Feb. 2015, P. Wilkin, J. A. Kennerley, F. Rakotonasolo, M. Hamido $\mathcal{E}$ M. Tsaratiana 1674 (K!, TAN!).

CONSERVATION STATUS. The specimen data cited above and field surveys to date suggest that Dioscorea irodensis occurs at no more than three localities. $D$. irodensis is only known to be extant at one locality south of Irodo village on the banks of the Irodo River, where it was found in 2015 and 2016 (see Map 1). It has not been possible to cross the Irodo River during field activity in 2015 and 2016 to survey the subpopulation represented by the 2002 specimen (De Block et al. 1079). In March 2016, a field team spent a day locating the coordinates of the Sahafary forest specimen (Rogers et al. 1149) and searching other suitable habitat in Sahafary forest. The specimen was collected in highly degraded vegetation on the edge of a Eucalyptus plantation. No plants of $D$. irodensis were seen anywhere in Sahafary. If present they would certainly have possessed above ground organs in March, thus the subpopulation has either been eradicated through habitat degradation and loss or there is an error in the GPS coordinates, perhaps caused by use of an older GPS model. For the present we must assume the former. It is likely that the subpopulation represented by De Block et al. 1079 is extant given its isolated location, so we recalculated EOO and AOO excluding only the Sahafary forest data point. This gave an $\mathrm{EOO}$ of less than $1 \mathrm{~km}^{2}$ and AOO of $8 \mathrm{~km}^{2}$ based on a standard cell width of $2 \mathrm{~km}$. Both are below the CR threshold.

In addition to habitat loss and restricted $\mathrm{EOO} / \mathrm{AOO}$, Dioscorea irodensis appears to be threatened by limited population size and extraction for use as food. At the site where it known to be extant, 10 adult plants were seen in 2015, of which 4 were female, and 15 in 2016, of which 5 were female. There is a limited reservoir of juvenile plants and a much more substantial one of seedlings with one or two leaves. A conservative estimate of generation length is 10 years; this is based on the authors' experience of cultivating wild Dioscorea species from Madagascar from seed. Thus it could be 8 or 9 years before seeds are produced by plants that are currently juveniles or seedlings. We are in the process of acquiring data on the abundance of these life history stages via plot surveys. Approximately 80 seeds were collected for banking by the Millennium Seed Bank Partnership in March 2015. The sacred forest in which the subpopulation is found has an estimated 100 


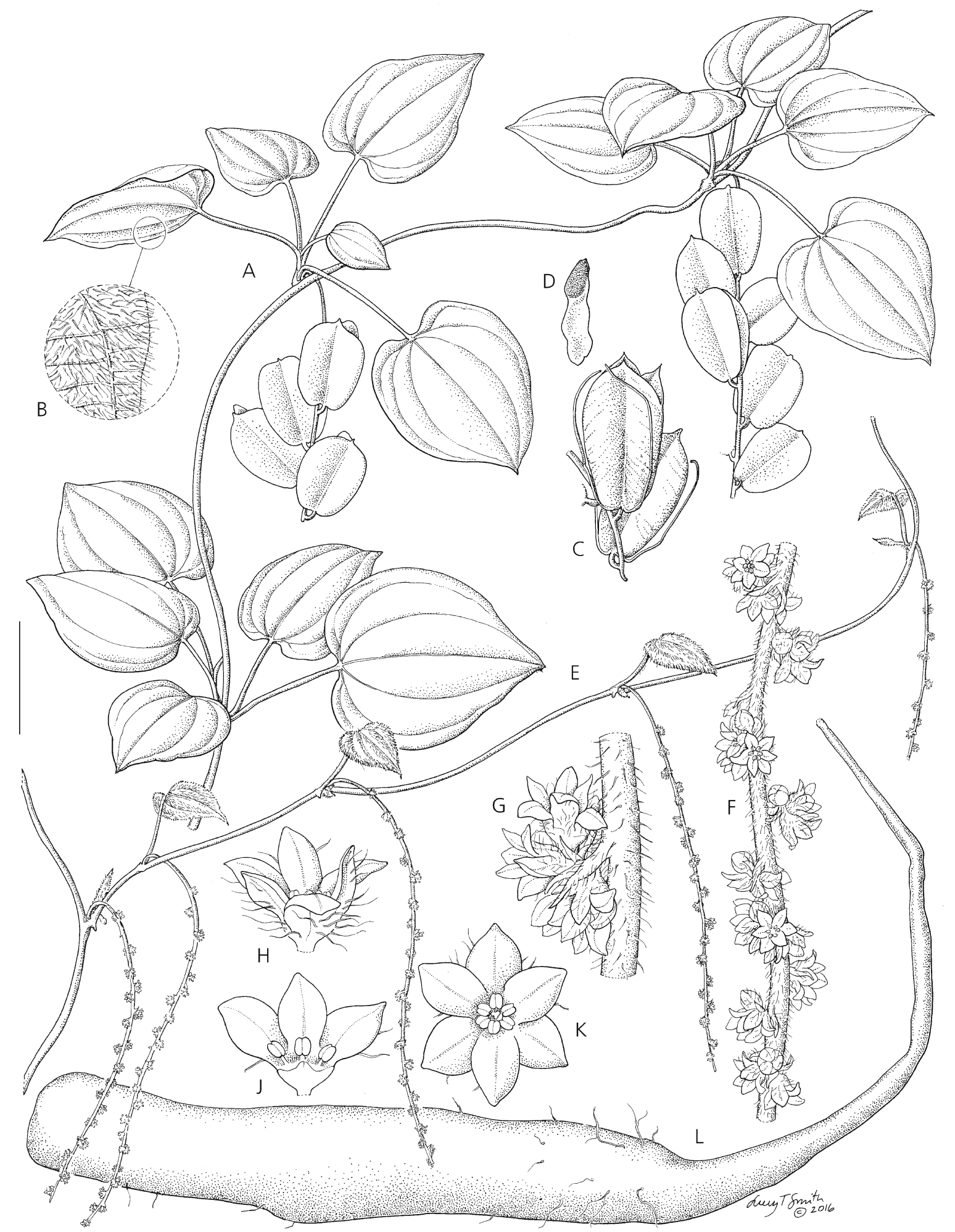

Fig. 1. Vegetative and reproductive organ morphology in Dioscorea irodensis. A habit of fruiting plant, showing leaves borne in clusters of up to 7 on short herbaceous branches; B detail of coarse, erect to spreading indumentum; C dehisced capsule; D seed and seed wing; E habit of male flowering plant with leaves in early development; $F$ part of a male inflorescence showing condensed cymules of flowers; $G$ a single cymule showing the cymule bract and inflorescence axis indumentum; $\mathrm{H}$ side view of a male flower showing pubescent tepal external surfaces; J half male flower showing three stamens, torus morphology and pistillode; $\mathrm{K}$ flower viewed from above showing inner and outer tepal whorls and anther presentation; $L$ tuber drawn following its usual orientation in the soil and curved apex that subtends a shoot. Scale bars: $A, E=2.5 \mathrm{~cm} ; \mathrm{B}=5 \mathrm{~mm} ; \mathrm{C}, \mathrm{D}=2 \mathrm{~cm} ; \mathrm{F}=4 \mathrm{~mm} ; \mathrm{G}=2 \mathrm{~mm} ; \mathrm{H}-\mathrm{K}=1.5 \mathrm{~mm} ; \mathrm{L}=6 \mathrm{~cm}$. DRAWN BY LUCY SMITH. 

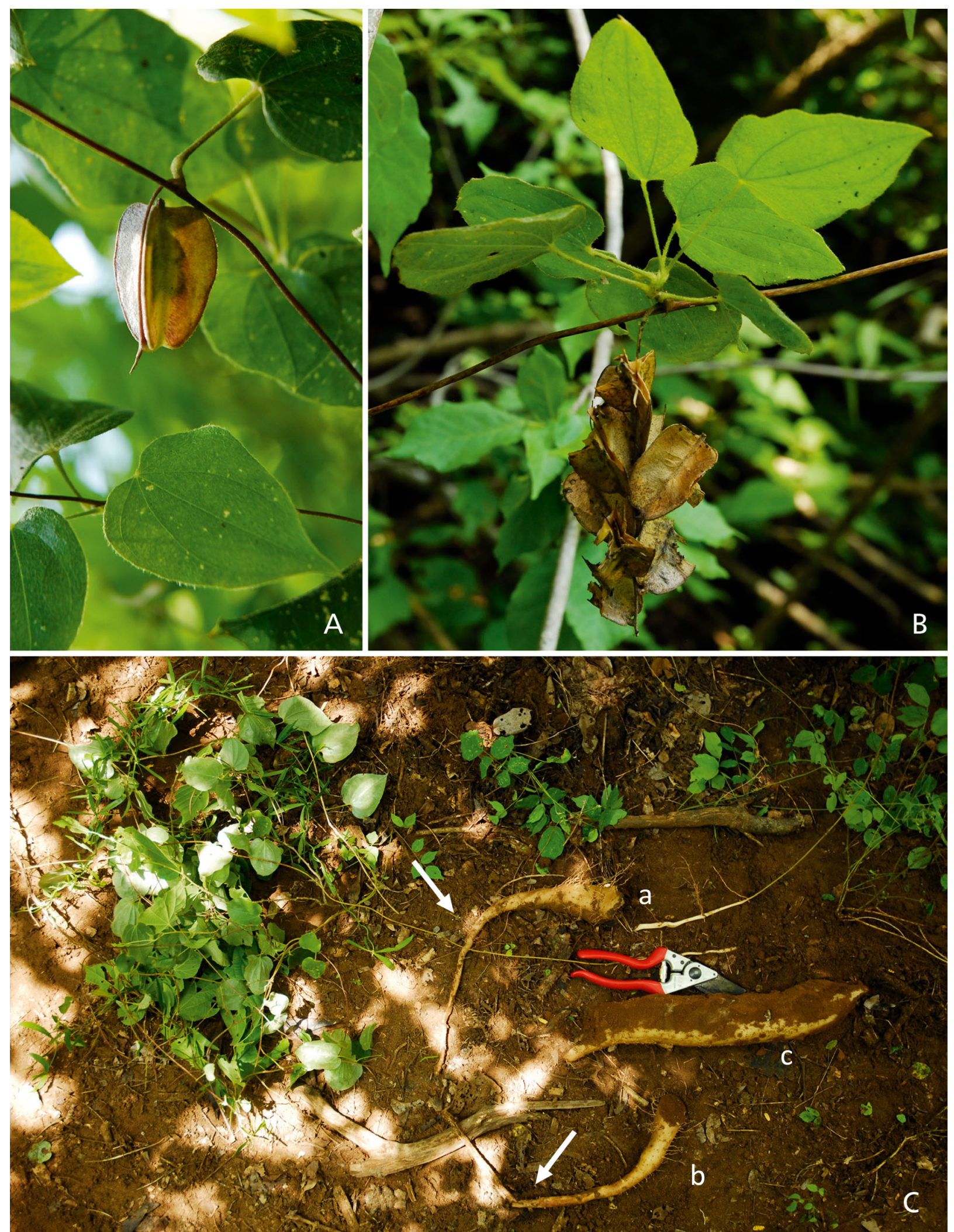

Fig. 2. Photographs of Dioscorea irodensis showing its vegetative morphology in fruit and underground organs. A leaves and an infructescence reduced to a solitary submature capsule; B node with a cluster of leaves on a short lateral shoot showing an infructescence at dehiscence; C two tuber apices (current (marked a) and previous year (b)) and separated body of current year's tuber (c) with stem and leaves disentangled from surrounding vegetation. The size and curved apex of the tuber (indicated by arrows) linked to its horizontal habit is shown. 
yam extraction holes, of which at least 20 appear to have been made within the last 12 months. Whilst timber extraction from the forest is culturally forbidden, removal of non-timber forest products is not. It is likely that any undiscovered subpopulations face a similar level of extraction which appears to be unsustainable. The village of Irodo has recently agreed to join the Darwin Initiativefunded project "Conserving Madagascar's yams through cultivation for livelihoods and food security". The principal shared goal will be to conserve $D$. irodensis and $D$. maciba Jum. \& H. Perrier through cultivation alongside the winged yam $D$. alata $\mathrm{L}$. The productivity of the latter should drive down demand for wild-harvested yams. We will also collect further seed for banking and duplicate living accessions elsewhere as far as possible.

In accordance with IUCN (2001) criteria, these data and observations suggest Dioscorea irodensis should be designated as CR A2acd+4acd; Blab(i, ii, iii, iv, v)+2ab(i, ii, iii, iv, v); C1+2a(i); D (Kennerley \& Wilkin, in prep.).

ETYMOLOGY. Named for the village of Irodo and the Irodo River valley where this species is found.

VERNACULAR NAME. Bemandry in the village of Irodo. This name appears to be applied particularly to species with horizontal tubers, for example the element of Dioscorea soso Jum. \& H. Perrier sensu lato with the same tuber habit.

USES. Tuber edible cooked. Rather watery following cooking and thus not fully satisfying the appetite. Dioscorea maciba, known as batatala in Irodo, is the more sought after species of the two that are found in the Irodo valley and surrounding areas. Not believed to be sold in markets but consumed usually in March/April. NOTES. The specimen de Block et al. 1079 was included within Dioscorea sambiranensis subsp. bardotiae Wilkin by Wilkin et al. (2009) as an atypical element. Its removal to D. irodensis restricts the known distribution of D. sambiranensis subsp. bardotiae to the Montagne des Français (just one specimen) and the Réserve spéciale d'Ankarana and surrounding limestone outcrops. The resulting reduction in $\mathrm{EOO}$ and $\mathrm{AOO}$ is likely to increase the threatened status of that subspecies from Vulnerable (Wilkin et al. 2009) to Endangered and this is confirmed by recent unpublished EOO and AOO results obtained from GeoCAT.

\section{Acknowledgements}

Our principal acknowledgement is to the Darwin Initiative as funders of project 22-005, "Conserving Madagascar's yams through cultivation for livelihoods and food security". We also acknowledge The Lord Faringdon Charitable Trust for funding fieldwork in February 2015 that enabled confirmation that this species was distinct and undescribed. We also wish to thank the people of the Irodo Base-Community for their help and hospitality, especially M. Paul, M. Moustafa and Mme Berthine. We welcome the com- munity joining those engaged in the Darwin Initiative project with a view to conserving Dioscorea irodensis (Bemandry) and D. maciba (Batatala) together. Thanks are also due to Madagascar National Parks in Anivorano, especially M. Hamido, Mr Ramiandrarivo Liva Hariniaina, Directeur des Aires Protégées Terrestre (DAPT) — Ministère de l'Environnement, de l'Ecologie, de la Mer et des Forêts (MEEMF) for issuing collecting permits, and Mr Zafimandimby, Chef Cantonnement in Ambilobe for their help. Finally, we thank Steve Bachman for his input into the conservation status assessment and Dr Hélène Ralimanana, Dr Franck Rakotonasolo, Landy Rajaovelona, Hajatiana Rakotoarimanana, Roger Rajaonarison and Joel Rakotonirina for their facilitation of this research, and the anonymous reviewers who helped to improve the manuscript

Open Access This article is distributed under the terms of the Creative Commons Attribution 4.0 International License (http://creativecommons.org/ licenses/by/4.0/), which permits unrestricted use, distribution, and reproduction in any medium, provided you give appropriate credit to the original author(s) and the source, provide a link to the Creative Commons license, and indicate if changes were made.

\section{References}

Bachman, S., Moat, J., Hill, A. W., de la Torre, J. \& Scott, B. (2011). Supporting Red List threat assessments with GeoCAT: geospatial conservation assessment tool. In: V. Smith \& L. Penev (eds), eInfrastructures for data publishing in biodiversity science. Zookeys 150: 117 - 126 (Version BETA).

IUCN (2001). Red List Categories and Criteria: Version 3.1. http://www.iucnredlist.org/static/ categories_criteria_3_1 [accessed 2016-04-07].

IUCN Standards and Petitions Subcommittee (2014). Guidelines for using the IUCN Red List Categories and Criteria. Version 11. Prepared by the Standards and Petitions Subcommittee. Downloadable from http:// www.iucnredlist.org/documents/RedListGuidelines.pdf [accessed 2016-04-07].

Kennerley, J. A. \& Wilkin, P. (in prep.) Dioscorea irodensis. The IUCN Red List of Threatened Species.

Shorthouse D. P. (2010). SimpleMappr, an online tool to produce publication-quality point maps. http:// www.simplemappr.net [accessed 2016-04-07]

Thiers, B. (2012). Index Herbariorum, a global directory of public herbaria and associated staff. New York Botanical Garden's virtual herbarium. Available from: http:// sweetgum.nybg.org/ih/ [accessed 2016-04-07].

Viruel, J., Segarra-Moragues, J., Raz, L., Forest, F., Wilkin, P., Sanmartín, I. \& Catalán, P. (2016). Late CretaceousEarly Eocene origin of yams (Dioscorea, Dioscoreaceae) in 
the Laurasian Palaearctic and their subsequent Oligocene-Miocene diversification. J. Biogeogr. 43: 750 - 762.

Wilkin, P., Schols, P., Chase, M. W., Chayamarit, K., Furness, C. A., Huysmans, S., Rakotonasolo, F., Smets, E. \& Thapyai, C. (2005). A Plastid Gene Phylogeny of The Yam Genus, Dioscorea: Roots, Fruits And Madagascar. Syst. Bot. 30: 736 - 749.
Hladik, A., Jeannoda, V. \& Weber, O. (2009). The threatened edible yams of the Dioscorea sambiranensis R. Knuth species complex: a new species and subspecies. Adansonia 31: 249 - 266.

\& Randriamboavonjy, T. (2012). Nomenclatural changes in yams of Madagascar (Dioscorea: Dioscoreaceae). Kew Bull. 67: 63 - 67. 